\title{
Educational innovations in Eastern Countries. Final Conference of Erasmus + project Fostering Competencies Development in Belarusian Higher Education
}

Innovaciones educativas en los paises del Este. Conferencia final del proyecto Erasmus + Fomento del desarrollo de competencias en la Educación Superior de Bielorrusia

Danguole Bylaite - Salavejiene ${ }^{1}$

\begin{abstract}
Erasmus + KA2 programme project Fostering Competencies Development in Belarusian Higher Education - [FOSTERC] consortium partners have met for the Final Conference in Minsk, Belarus, on the $6^{\text {th }}$ of December 2019. It was an exciting moment. FOSTERC consortium worked together since 2016, many meetings, trainings, common research, design of a tool to gather primary information from Belarusian Higher Education Institutions and the implementation of a new model based on competencies development following the Bologna process. The final FOSTERC event has summarised transformations and novelties that have been created in Belarusian higher education institutions during the last three years. This text shortly reviews some insights and solutions that have been discussed during the FOSTERC conference in Minsk.
\end{abstract}

\section{KEYWORDS}

Higher education, modes of teaching \& learning, labour market, study programme, curricular, mobility, internships, lifelong learning, Belarus

1 Vytautas Magnus University. Education Academy, Institute for Professional Development in Vilnius [Lithuania] Email: danguole.bylaite-salavejiene@vdu.lt 


\section{RESUMEN}

Los socios del consorcio del proyecto del programa Erasmus + KA2, que lleva como título "EI Fomento del desarrollo de competencias en la educación superior de Bielorrusia" - [FOSTERC], se reunieron para celebrar la Conferencia final en Minsk [Bielorrusia] el 6 de diciembre de 2019. Fue un momento emocionante. El consorcio FOSTERC lleva trabajando en buena sintonía y sinergias desde 2016, celebrando conjuntamente reuniones de trabajo, seminarios internacionales, formación e investigación en conjunto, el diseño de una herramienta de información y la implementación de un nuevo modelo educativo basado en el desarrollo de las competencias siguiendo el proceso de Bolonia. La conferencia final del FOSTERC ha resumido las transformaciones y novedades que se han creado en las instituciones de Educación Superior de Bielorrusia durante los últimos tres años. El presente texto revisa brevemente algunas ideas y soluciones que se han discutido durante la conferencia final del FOSTERC en Minsk.

\section{PALABRAS CLAVE}

Educación Superior, métodos de enseñanza y aprendizaje, mercado laboral, programa de estu-dio, curricular, movilidad, prácticas formativas aprendizaje permanente, Bielorrusia 


\section{FOSTERC PROJECT ACTIVITIES}

Dr. Adela García-Aracil, main project coordinator of the Universitat Politècnica de València represented by the institute INGENIO [CSIC-UPV], Spain, has paid attention to the main objective of the FOSTERC project - to support modernization of governance, management, functioning and quality of Belarusian Higher Education Institutions. Dr. Adela Garci-Aracil noticed that the consortium of 16 partners has tried to reach the goal by improving higher education graduates' learning outcomes, based on competencies [knowledge, skills and attitudes] development; designing new curricular, focusing on graduates' competencies; upgrading and improving teaching and learning methodologies.

Dr. Rosa Isusi-Fagoaga, external expert of the University of València represented by the institute IUCIE, Spain, has discussed FOSTERC in the context of tracer studies. She noticed that FOSTERC survey methodology is innovative one as involved to survey activities both students, teachers and employers. In this framework, the innovative FOSTERC on-line survey system was presented in detail by Dr. Alexander Rytov, Belarusian State University.

\section{INSIGHTS FROM FOSTERC SURVEY}

Assoc. Prof. Dr. Yury Bialykh, Vice-Rector for Academic Affairs, Yanka Kupala State University of Grodno, Belarus, discussed FOSTERC survey results by taking into account Belarusian higher education graduates' opinions. Survey showed that Belarusian labour market requires the highest proficiency of such competencies as ability to acquire the new knowledge, to adapt to change, flexibility, ability to work under pressure, stress resistance, to take part in continuing professional development. Assoc. Prof. Dr. Yury Bialykh has taken attention to another issue of the Higher Education in Belarus as the FOSTERC survey data proved that higher education studies rather contributed to the development of competencies such as the ability to communicate in a foreign language, to inspire others, to fulfil leader duties, to negotiate effectively and to take decisive actions in a situation of uncertainties.

Assoc. Prof. Dr. Alexandra Pozniak, Belarusian State Pedagogical Maxim Tank University, continued FOSTERC data review by taking into attention higher education teachers' role in modern university. She noticed the importance of teachers' active participation in digital educational environment creation, as well as in updating study programmes and learning materials, methodology, taking part in team work, professional networks, professional development activities and in strengthening research activities in Belarusian Higher Education.

Assoc. Prof. Dr. Nadezhda Boreiko, Vice-Rector for Studies of Plotsk State University, Belarus, discussed the issue of stakeholders' cooperation. She mentioned that FOSTERC survey data inspired academic community to innovate some aspects of home university work. One of them was to improve efficiency of university management. There were introduced principles of corporate management and corporate social responsibility in Polotsk University. Representatives of regional and local employers have joined Polotsk University Council. 


\section{MODERNIZATION OF HIGHER EDUCATION IN BELARUS}

FOSTERC survey data has guided toward modernization of different aspects of Higher Education in Belarus.

Dr. Igor Titovich, Vice-Rector of National Institute for Higher Education [NIHE], Belarus, highlighted FOSTERC project results on national level. He presented new educational standards in Belarusian Higher Education, which focus on use of competency-based approach, including learning outcomes, modular approach, development of $1^{\text {st }}$ and $2^{\text {nd }}$ cycle standards, as well as new curricula development model, discussing change of studies duration and the broader involvement of different stakeholders. National Institute for Higher Education [NIHE] in Belarus has developed Guidelines for Assessing Learning Outcomes in Case Translation, Restoration and Academic Mobility [draft), as well as National Qualifications Framework for Higher Education.

\section{REALIZATION OF COMPETENCY-BASED MODULAR APPROACH IN BELARUSIAN HIGHER EDUCATION}

Assoc. Prof. Dr. Sergey Severin, First Vice-Rector of Brest State University after A. Pushkin, Belarus, discussed realization of competency-based approach in Master degree programmes at home university. Assoc. Prof. Dr. Sergey Severin has taken attention to innovative Master degree programmes "Innovations in Teaching Foreign Language" [practical oriented study programme) and "Lingvodidactics" (science oriented study programme). These study programmes integrated new modules and bilingual module as well.

Prof. Dr. Valentina Simhovich, Belarusian State Economic University, presented new methods for competence building at home university. She has taken attention to main factors in realization of competency-based approach: university educational environment, curricula content, quality of methodological support, employers' participation. Professor discussed experimental work conducted in realization of Master degree programme "State Regulation of National and Regional Economy".

Assoc. Prof. Dr. Michail Koshman has shared his reflections on implementation of competencybased approach at Francisk Skorina Gomel State University, Belarus. Prof. Dr. Michail Koshman discussed the experimental work that has been conducted in realization of Master degree programme of "Psychology". The main focus was taken to Master degree students' professional and personal development in the innovative educational space of home university. Experimental work had a focus to develop students' professional competencies that are relevant and required in labour market. 


\section{RECOMMENDATIONS}

FOSTERC Final Conference in Minsk 2019 came to conclusion that many important changes have been implemented in Belarusian Higher Education during the last three years [2016-2019]. The innovations have been implemented on national level, regional and local level for building competency-based and high quality of Higher Education in Belarus. However, the Final Conference participants noticed that there is lack of methodological support in realisation of competencybased approach in Belarus Higher Education. Belarusian partners expressed the need for trainings and exchange of good practices with the EU partners.

\section{ACKNOWLEDGEMENTS}

The research for this paper was conducted as part of the Research project ref. 574087EPP-1-2016-1-ES-EPPKA2-CBHE-SP [2016-3219], Fostering Competencies Development in Belarusian Higher Education [FOSTERC] funded by The European Commission. The views expressed in this paper are not necessarily the views of That organization.

\section{REFERENCES}

Higher Education Reform Experts. Activity report 2018. https://eacea.ec.europa.eu/ sites/eacea-site/files/here activity report 2018 web.pdf

Erasmus + KA2 programme project Final Conference materials. 2019.

https://fosterc.bsu.by/мероприятия-проекта/итоговая-конференция-международного-проектаerasmus-содействие-развитию-компетенций-в-белорусском-высшем-образовании-fosterc/материалы-конференции 